\title{
An ethnographic study on managing diversity in two Protestant theological colleges
}

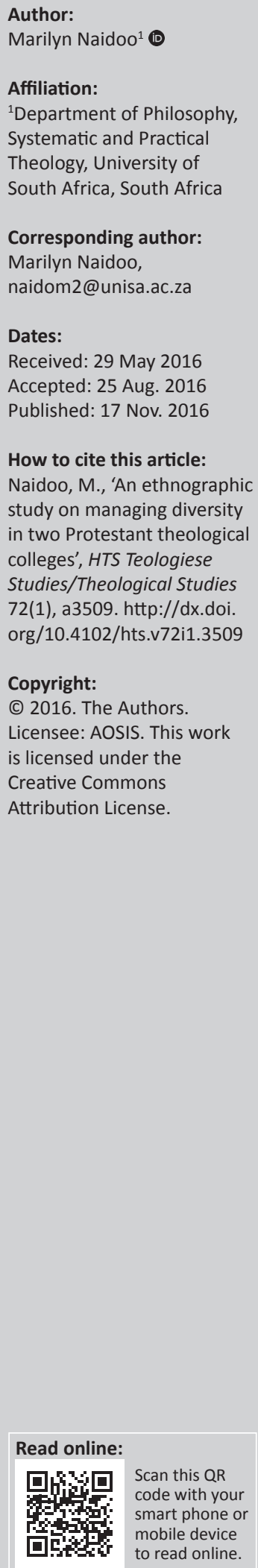

For many reasons Christian higher education institutions struggle to embrace diversity. Diversity is a relationship of mutuality, where differences are engaged and respected. This study aimed to understand diversity management via the institutional culture to understand how these interactions of dealing with diversity form and prepare future religious leaders. These issues are highlighted through two case studies conducted in the main-line Protestant tradition. Diversity was represented in issues of race, ethnicity, class, gender and sexual orientation, which have an interlocking nature. Findings suggest a colour-blind theology in one institution, perpetuating surface change, and a lack of structure, alignment and capacity in diversity in the other institution. In both institutions diversity was not linked positively to ministerial identity formation to make a significant difference. This study highlights the lack of consciousness of the way in which institutions are organised, which then holds direct consequences for students, identity and transformation.

\section{Introduction}

In our post-apartheid democracy, churches are struggling to reconceptualise their role in society (Kuperus 2011:279). They have gone through a process of reformulating their identity and have restructured theological education for all their members. This has resulted in growing multicultural student bodies, reflecting a wide spectrum of cultural backgrounds, personal histories and theological commitments and representing diversity in race, ethnicity, culture, class, gender, age and sexual orientation (Dreyer 2012:505). These issues of diversity are theologically complicated and contested as they are attached to religious dogma, making it challenging to implement. At the same time, the theological foundations of institutions 'provide a strong biblical and moral rationale for addressing diversity-related social justice' (Nussbaum \& Chang 2013:9).

In South Africa there is scarcity of literature on how diversity is attended to in theological institutions and this broader theoretical discussion on diversity within the South African context can be accessed in previous publications (see Naidoo 2014, 2015). One wonders how theological institutions are dealing with diversity while forming students within their institutional culture, as this kind of socialisation is seen as most formative (Hindman 2002), or how future ministers are being prepared to handle issues of diversity in increasingly diverse communities. It is important to raise this issue because in South Africa, race still predominates, with a continuing legacy of inequality and unjust power dynamics; hence suspicion abounds in trying to find constructive proposals to managing diversity.

Meyer (2009) identifies four reasons why faith-based higher education institutions must be concerned about diversity:

First Christian colleges and universities must reckon with the history of discrimination against women and racial/ethnic groups and their participation in discriminatory systems. Second is the concern for students to grow through cross-cultural experiences as they prepare to work in an increasingly diverse world. Valuing difference, developing multicultural competence and being globally minded are essential skills in today's workforce. Furthermore colleges and universities exist to serve the needs of their constituents, which are changing and becoming more diverse. Finally diversity is fundamentally a matter of justice. (p. 32)

The challenge, as Steyn reminds us, 'is how to value what different groups may bring to the collective while, at the same time, maintaining cohesive societies' (2011:7). With the recognition that social markers of difference and privilege are neither innate nor innocent but the result of socially structured boundaries between individuals or social groups (Cross \& Naidoo 2012), such an orientation enables:

Note: This article is part of the Special Collection titled 'Negotiating Diversity in Christian Communities', sub-edited by Marilyn Naidoo of UNISA and Stephan de Beer of the Centre for Contextual Ministry, University of Pretoria. 
...a radical look at constructions of difference that underpin institutional culture and interpersonal interactions, and moves beyond merely tolerating or assimilating differences into dominant practices, which is the case for some approaches to diversity. (Steyn 2011:19)

The purpose of initiatives related to diversity is to examine the unrecognised ways in which power assumptions (Bernstein 2000:5) embedded in institutional culture might disenfranchise certain groups of students (Riebe-Estrella 2009:19), whether knowingly or unknowingly, and undermine the educational mission of empowering students for work.

\section{The research project}

This project was a 3-year study in two private Protestant theological institutions to understand the critical role of the theological institution's culture in relation to student formation. To do this, firstly, the concept of diversity was explored within the institutional culture so as to understand how these interactions of dealing with diversity ultimately formed and prepared future religious leaders. The second aim was to establish whether theological institutions exhibit distinctive cultures in dealing with diversity. Due to space limitations, only the first aim will be attended to in this article.

\section{Theoretical framework}

The theoretical framework of this research is built on culture, which becomes the major lens through which to understand educational organisations and their dynamics (Ouichi \& Wilkins 1985; Smircich 1983). However, more than the identity of a community, culture refers to processors, categories and knowledge through which a community is defined (Donald \& Rattansi 1992). Students are formed by the institution's culture as they interact with it and with others in the learning context, which functions as a plausibility structure for nurturing and sustaining the culture's shared meanings and symbols (Geertz 1973). Swindler (1986:273) extends Geertz (1973) perspective by emphasising that culture includes shared practices and ideas and interprets culture as 'tool kits' of symbols, stories, rituals and worldviews that provide the cultural components that people use to construct 'strategies of action'. In conducting an analysis of the culture in a theological institution, the institution needs to give reasons for its beliefs and actions. Of course, this may be thought of as its cultural tool kit, but it also implies the involvement of orientating actions toward some normative goal: the reason for one's beliefs and actions towards diversity.

Theological seminaries constitute a common organisation field that, in turn, participates more broadly in the organisational field of higher education, especially professional education. Professional education focuses on how students learn and internalise the professional role (Kleinman 1984; Schon 1991), for example in the professions of medicine, law or engineering. The professional socialisation of church ministers is referred to as 'ministerial formation', viewed as a multifaceted activity involving critical thinking, the acquisition of knowledge, skills development, religious identity formation and the development of the ministerial and spiritual maturity expected of church ministers (Naidoo 2012:3). Ministerial formation is about ongoing development of identity, reclaiming one's culture, gender and other aspects of identity; it is part of moving towards greater authenticity (Borysenko 1999; Palmer 2000). Froehle, Maloney and Lassiter (2014:20) speak of the 'said, the unsaid and the unsayable' in ministerial formation. The 'said' is the known history and traditions, the 'unsaid' are the undercurrents in the life of the community that are avoided and threatening and the 'unsayable', or heretical discourse, is that which goes to the core constructs of power. Ministerial formation around issues of difference should provide space for these discussions in identity formation and so that students learn from those perceived as the 'other' or as 'different' (Conde-Frazier, Kang \& Parrett 2004). The question at play here is how students might relate theology to their own context while also attempting to understand the other, such that their own presuppositions are challenged and their work in society becomes more effective.

\section{Methodology}

This project is a descriptive, explorative study in the qualitative research paradigm (Neuman 2006:46) using an ethnographic approach. Critical ethnography is an attempt to expose the hidden agendas and describe power relations at play (O'Reilly 2009:55). It provides a unique method for looking beyond the surface and generally critiquing the taken-for-granted. Ethnography helps to bridge the gap between experience and discourse, expanding the sources and hermeneutical lenses to include suppressed voices and stigmatised cultural traditions.

To understand the role of the institutional culture, special focus was placed on a campus climate framework (Hurtado et al. 1998), which focuses on compositional diversity (diversity of student body and staff), the behavioural (social interactions and diversity in the curricular and co-curricular) and psychological (perceptions of racial or ethnic tension, discrimination and prejudice) dimensions, and the historical legacy of inclusion or exclusion within an institution.

Within this institutional culture students are being shaped within diversity and socialised in how to respond to diversity. The way in which diversity is managed could create a source of division or it could be used as a positive element in religious identity formation.

\section{Sample}

The sample consisted of two private theological training institutions from within the broad Protestant tradition - one college from the independent tradition (Institution A) and one from the main-line tradition (Institution B). These selected church traditions have separate intellectual, religious and social worlds and in no way do the two institutions represent the totality of those two broader religious traditions. 
Theologically both these institutions are quite different in terms of their understanding of the low and sinful state of humanity, the Bible and its authority and salvation in other religions. To explore whether institutions respond differently and exhibit different cultures (the second aim of the study), a comparative study of theological institutions was made.

The selection was based on four criteria: that it be an accredited academic programme with the Department of Education, provide education for church leadership, comprise a residential educational community with contact teaching sessions and represent different Christian traditions. The selected institutions allowed access to their campuses and placed no restrictions on what could be observed or who could be interviewed. This placed a degree of risk on the part of the institution and the researcher guaranteed anonymity. While such caution is not typical of ethnographies, disguising names and omitting some specific information about the institution and their histories was necessary ( $\mathrm{O}^{\prime}$ Reilly 2009:62) because theological training institutions in South Africa comprise a small universe and it is possible to identify institutions.

\section{Data collection and analysis}

Data were collected through ethnographic fieldwork over a 2-year period. An equal amount of time was spent in each institution conducting around 20 formal student interviews, 4 focus groups with students and around 10 staff interviews. Participant observation was key; observing, interacting and gaining intimate knowledge of students' experiences through attending classes, visiting student residences, going to chapel services, attending recreational activities, taking meals with students on and off campus, even attending a graduation ceremony. This multipronged strategy was supported by short notes, video recordings of events and institutional documents. The idea was to let the formative process unfold and watch students and staff as they experienced and negotiated their institution's culture. This insider (emic) approach investigated what had meaning for participants and how they imagined and explained things ( $\mathrm{O}^{\prime}$ Reilly 2009:150).

The analysis was done using thematic analysis (Creswell \& Plano Clark 2011:156), which involved identifying themes or patterns of cultural meaning from interviews and the observational data collected. Coding was done inductively. The resulting thematic structures were interpreted by seeking commonalties, overarching patterns, theoretical constructs and explanatory principles grounded in the particulars of the two cases. Emergent patterns were reflected on using critical discourse theory (Wodak \& Chilton 2005), which aims at making opaque structures of power relations and ideologies visible.

\section{Findings}

The two sampled colleges are integrally related to the denomination in terms of its vision, mission and resourcing.
They are also the official learning centre of the denomination and the most prominent of all training institutions. All students were preparing for church ordination, studying a 3-year degree or diploma programme to serve in a congregation or local Christian community. There was an expectation that students came with a level of personal commitment to the stated belief system of the church denomination and the college and that they were there to be equipped professionally and vocationally.

The campus of each institution was located in an urban area and was owned by the church denomination with a series of buildings, including classrooms, a library, staff offices, a chapel, student residences, staff residences, dining and recreation rooms. As a residential community, each institution had particular activities throughout the day, meals, prayer time, classes, group activities, church services, recreational activities and community outreach.

Students represented diversity in terms of race, gender, ethnicity, nationality, language, age, class, educational background and career stage. The findings reflected mostly on race and gender, which was uppermost in the minds of interviewees, with some mention of sexuality. Possibly the latter is viewed with scepticism as it is viewed as a form of moral and cultural relativism (Perez 2013:22). The absence of discourse on the other dimensions of diversity highlighted how little awareness there is of how entrenched the norms are, resulting in virtual invisibility of any contestation of identity (Steyn 2011:22).

\section{Institution A}

Institution A was part of the independent church tradition, which usually comprises Pentecostals, Charismatics and the African independent churches. Churches in this tradition are recently established, can be loosely formed, are mostly autonomous in their church governance and historically have been politically conservative (Anderson 2005:58). These churches tend to focus on personal and public integrity, as well as bringing discipline to Christian and social life according to God's plan as inscribed in the Bible. They 'emphasize personal salvation and imminent return eschatology that translates into a minimal desire for immediate socio-political engagement' (Balcomb 2004:6).

The student body on campus averaged 35 students, with 25 males and 10 females. The majority were young black Africans, with four coloured and seven white students. The average age was 25 years. The teaching staff comprised six full-time teaching staff and three part-time lecturers; all were white except one black African male lecturer.

In terms of how diversity was attended to within the institutional culture, there was no formal policy or interventions in place. Rather from the college there was an official stance of non-racism, non-sexism and equal treatment of all in the constitution of the church. Within the formal curriculum there were modules titled 'Knowing Yourself and 
Others' and 'Spiritual Formation' that dealt with self and cultural awareness. In addition, there was a mission outreach trip each year and this was intended to 'educate in ministering cross-culturally'. Informally there were structures like the formation groups, which were intentionally racially and gender diverse for students to journey together spiritually. Within the residential campus there were communitybuilding activities like work days and community outreaches.

What was noticeable about this campus was the awkwardness in talking about diversity issues, especially the issue of race - the principal immediately affirmed that 'we do not have a problem here - we are brothers and sisters in the Lord and we do not see colour'. In fact it would seem that people are unaware that these issues exist, which is typical among the majority groups as a result of their structural position in the majority (Tatum 1997). This 'colour-blind' position maintains the status quo and tries to suppress and gloss over prejudice by professing not to see colour. It would seem that talking about race and emphasising ethnicity only causes divisions, and as the principal stated, 'we should focus on what we have in common, our faith, and not what makes us different'. Students felt that talking about the race issue was seen as divisive:

Things will continue because it has been happening for many times because when you come to a place with your own physical eyes you will see that this has been happening for such a long time. So when you try to bring something new, it is like you are the one who is bringing the division.

Students were generally guarded and careful when answering questions, while others were defensive, like the head of the Student Representative Council:

My experience has been 95\% positive, with very little open racism or anything like that. I am not saying maybe it does not exist. It might exist, some individual might have a problem with it ... most of the students here are post-apartheid students if you look at their age and what apartheid used to be they have no comprehension. When you talk to them, yes, they have heard about it, but they have never experienced it.

This comment was revealing from a student who showed little awareness of the extent that he has been privileged by the system, invisible to most white people (McIntosh 2005). He spoke of racism as a historical legacy and not as a current social problem. Yet, in interviews with black African students the topic of race on campus was never far from the surface. As Steyn suggests, 'the people who experience the effects of racism and sexism are the most aware of the forms it takes' (2011:27). Students stated that:

[Referring to the students] I think in everyone's mind there is something about the colour of your skin. We think about this but we cannot speak about it. (Participant)

On the surface we are together, we agree but inside, you know, inside the person, it is a struggle. (Participant)

However, black African students were not so forthcoming in focus groups; the conversation tended to be polite and pietistic. It is important to recognise that the act of speaking is itself influenced by the problems related to how one is perceived in racialised ways in these spaces. Race was a certain indicator of identity. Also seen in the classroom environment and at recreational activities, students socialised in distinct race or language groups. The student residences were not used as a structure for racial and cultural integration (Paredes-Collins 2013:132), but rather allocated on a first come, first served basis. If students cannot live in community cross-culturally then they have the opportunity to study via 'distance education', which seemed like a way to skirt the issue of cultural integration. Language also appeared to be divisive. The official languages of the college were English and Afrikaans and when Afrikaans staff and students conversed in the classroom, some students were not able to follow the conversation, which was viewed as intending to exclude. Afrikaans was seen as discriminatory by many black African students, as they were not afforded the luxury of studying in their mother-tongue language:

I ended up saying if you are going to present in Afrikaans be sure that I am going to leave because I am just wasting my time. I do not understand what you are saying. So this language issue, really we must not beat around the bush - we must deal with it straight. (Participant)

Because students were living together across cultures for the first time, the internalisation of apartheid stereotypes left students with suspicion of the other. In interviews, students spoke of incidents of racism in the residences, stereotyping, cultural misunderstandings, verbalisations of internalised oppression and domination:

Hidden agendas because actions speak louder than words ... there are other things that you can just see from the people but you cannot prove [a white person is bringing expired food for black people] ... that one I do not like it, it is wrong ... for me it is an insult. (Participant)

It is always a challenge to relate with different races especially if you believe more in another race than you do in another. (Participant)

To socialise it is always blacks with blacks and whites with whites. What I can say is even with the living arrangements, it is hard for you to stay with a white person because they decide where you should stay. So for us to relate we just have to greet each other in the morning. (Participant)

I remember last year they had to call the principal to address this thing of cultures, how people worship, how coloureds worship, how black people worship, because it was a problem - people felt that when that one leads he leads others away; there was tension. (Participant)

Issues of gender were highly contested as the traditional viewpoint of women in the broader church was strongly held. Even though the constitution of the church stated that female ordination was allowed, there were limits to their leadership as women could not act as overseers (regional leaders). Women were generally seen as inferior in that female students were training towards ordination while many churches do not ordain women or prefer not to do so. The majority of female students had not developed a gendered consciousness and seemed content to maintain the status quo. Among the staff, women were under-represented, 
with only one female lecturer. What is clear is that the intersecting of patriarchal cultures and the practices of the church serve to reinforce one another in the denial of the full dignity and worth of women.

Issues of sexuality in the college were dealt with from a clear perspective of non-acceptance. Being homosexual was viewed as sinful and in need of repentance or change, as reported in an incident of a student found to be a lesbian:

I do not think she went into ministry or anything like that, but because I think they [staff] did not know how to deal with such a kind of situation ... nobody said anything about it ... they just left it there. (Participant)

In this college there was a strong sense of conformity to biblical truth and it did not necessarily include the secular ideals of human rights. There was a strong focus on piety; hearts needed to be changed before structures could be changed. God's plan for the world and the redemption of human life was seen as an orderly one that was inscribed in the Bible. Secular society and liberal Christians who had ignored God's biblical plan for life must be shown its superiority to the human-centred principles they had endorsed.

With this kind of orientation, there was also a certain level of indoctrination as teaching went unchallenged, an antiintellectualism and lack of critical engagement with social issues. Students were not helped to think for themselves about important questions about identity, and they accepted uncritically the beliefs of the denomination and their home communities. Thus, in terms of understanding what diversity entailed, what was clear was how scriptural resources influenced and shaped their views on diversity. There seemed to be an unthinking biblical literalism in which issues were spiritualised:

We do not ignore that some problems may exist because of our frame of mind or because of what we were used to, but I refer to the Bible when it says you become a new man through Christ, no more Jews, no more Greeks. (Participant)

Informally [the door] will not always be opened [for women] ... [politically] is all about human rights, not necessarily about biblical truth, so I am saying we are speaking from that perspective. (Participant)

For me I think the Bible is very straightforward about homosexuality and we are representatives of God and his Word and we cannot compromise. I am not throwing that person away but I am not accepting. (Participant)

Because the individual's relationship with God was given ultimate importance in this institutional culture, cultural differences in how people think and live out their faith did not seem to be emphasised and were seen as not relevant to advancing an understanding of the Christian life. As a result, emphasising diversity was seen as a 'liberal political agenda' that had nothing to do with their faith (Perez 2013:32). It would seem that there was a fear that embracing diversity would result in the college's atmosphere becoming opposite to the faith, becoming politicised. At the same time it would seem that this approach was a half-hearted one towards diversity, typical of institutions that feel pressured to embrace multiculturalism (Fubara, Gardner \& Wolff 2011). Not wanting to be left behind, churches and colleges take the politically correct route (Abadeer 2009:188) without processing these politically correct statements of 'nonsexism', for example, and its implications throughout the life of the church and training institutions by aligning structures accordingly. As the principal in this college stated:

It took us time also to accept women into the ministry but now that we are bound by our own constitution - we had to do that and so we ended up accepting women and now we do have ordained women ministers ... [but] the [local] church is not accepting. (Participant)

Another example of the half-hearted approach was seen in the lack of racial and gender diversity in the teaching staff. Research has shown that faculty diversity, especially in race and gender, contributes to positive perceptions about institutional commitment and climate (Smith \& Schonfeld 2000:17). According to this college, the issue of staff appointments was the prerogative of the denomination. It would seem that issues were not dealt with directly and were seen as the broader church's issue, as the college was secondary to the larger denomination.

Among staff there was a general lack of awareness on the need for diversity, as the principal stated:

Since 2005 we have been a multicultural college and I think there was always a unity among our students; we get students with different personalities, from different cultures but I see that we are actually one family. (Participant)

This multicultural approach neutralises the pedagogical process by essentialising the concepts of race, ethnicity, gender and so forth (Hill, Harris \& Martinez-Vazquez 2009:18). Such an approach does not address issues of power relations that are at play at the very core of the daily lives of institutions. In addition, it assumes that the dominant group in the church culture is the faith that is common to all. The true way tends to be defined according to white conservative cultural interpretations. Here the institutional culture remains one of privilege for those who have held the power to maintain their dominance, making the educational enterprise fundamentally reflective of that same group (Riebe-Estrella 2009:20). What reflects the world of the dominant group is considered normative, while what is different is considered as peripheral and of less value. As a result this places the burden of conformity on those in the subculture who have been marginalised. As a student stated, 'apartheid was imposing, especially in our church, imposing the culture of people who are not even a majority'. In this high performance culture, leaders need to be seen saying and doing the right things. Students felt they could not express their opinions and hurts over racial issues without being labelled divisive and therefore unChristian. It also allowed discouragement and anger to build because students did not have a forum in which to express themselves. In cases like this fear can also creep in and manifest itself as indifference and selective 
non-involvement, defeating attempts at diversity. Many students were reluctant to come forward, as this could also impact their ordination prospects. This inevitably perpetuates a culture of silence; as a student stated:

You cannot go there today to the faculty and complain because now it will look like it will be me because there is no one who is ready to complain ... all of a sudden I am the one who is bad. (Participant)

The management of this institution felt that in relation to the larger church denomination, where churches were mostly monocultural, the college had made great strides in unifying different training systems and in focusing on treating all students equally. What was evident was a strong assimilation culture as the church tradition attempted to create a racially unified training system. This approach denies the linguistic and cultural capital that black students bring by absorbing them into the white hegemonic culture of the school (Steyn 2011:114). Educators felt that these matters of social integration should happen naturally. It would seem there was a commitment to social diversity as long as it was convenient and did not cause any disturbances within the college or its constituency.

\section{Institution B}

Institution B was part of the main-line Protestant church tradition. These churches are international, resource-rich, institutionalised and are some of the historic missionary churches in South Africa, which also include Anglican, Presbyterian, Methodist, Lutheran, Congregationalist and Catholic churches. As a church tradition, historically the Protestant churches were exposed to pluralism and viewed as a more politically and socially active society (Kuperus 2011:278). Generally in this tradition the world and the church are missing not order and discipline but inclusiveness and justice.

This sampled college had 58 students: 45 males and 13 females. The majority were black African, with three white, two Indian and five coloured students, including eight students from the broader African continent. The average age was 37 years. The teaching staff was composed of a multiracial group of eight full-time and two part-time lecturers. All staff were male, except for one female lecturer.

Because part of the mission of the college was to be 'contributors to social change and social cohesion and enablers of a truly transforming humanity', the issue of diversity had an important role to play. The college upheld 'the principle of equality and non-discrimination on any of the grounds set out in the Bill of Rights'. There was no policy on how diversity was managed or dedicated resources, except to state that there was an awareness of diversity, since the broader church was very diverse. Students were encouraged to be 'open to new ideas and comfortable living with differences of opinion and practice'. In the formal curriculum, modules titled 'Gender and Theology' and 'Ethics of Human Sexuality' were seen to be helpful, as well as a workshop on sexuality in 2012. In the chapel, the songs and liturgical design were aimed at being language and gender inclusive. Informally there were structures within the residential setting that dealt with spirituality and community life, such as formation groups, community-building activities and recreational activities.

At this college there was a general openness from staff and students to speak about issues of difference even though issues were seen as contested. However, even with a focus on appreciating diversity, there were many incidents reported of passive and active racism, even reversed racism with a majority black African student body by minority races:

The blacks they are in majority and they clique together, so whatever issue we will bring, or whatever issue there is - they [blacks] will stick together. (Participant)

I sometimes [feel] that black people automatically assume I am racist and I sometimes feel the need to prove that I am not racist. Sometimes it puts unnecessary pressure on me, so I do not know if I am wrong or right, but it could be because some people assume that white people are generally racist. (Participant)

From these comments it may be inferred that minority race groups are 'invited but not welcomed' (Abadeer 2009:195), which could prevent them from feeling a sense of belonging in the college. There were other incidents of tribalism, with the dominant African language/ethnic group being favoured, stereotyping and victimisation of first-year students, as students jostled for power in a new environment:

We realised that even though we have an orientation week, not much was done to break the cliques within different groups and that now creates problems because we now have people moving in their cliques, shutting out people - even when they are in their formation group they still sit together; they do not want to interact with the bigger group. (Participant)

In terms of the gender issue, the college encouraged students to embrace women as equals but there was resistance. The traditional view of women in the broader church impacts on how women are accepted and treated at college level. Gender issues were seen as a women's issue, to be addressed by women and not a matter for the entire college. In the classroom, there was sometimes only one female in an allmale class, making it difficult for gender issues to surface. Actually, in such situations there is a 'normalising of abnormalities' (Hill et al. 2009:12) and a trivialising of difference. The woman sticks out so much that she becomes a token rather than a genuine human being who brings difference to the social whole. There was also a lack of role models, as women staff were unrepresented, with only one female lecturer. Patriarchy and gender discrimination were rife and women generally did not feel supported, as this comment by a male student reveals:

I am a Zulu; others are Xhosas - back home women are not given positions and men are always taken as someone important, that men are above women. So you find that most of the people that are here are Xhosas, Zulus and some are Sothos who are coming from such backgrounds. I do not know about others like coloureds and whites, but as Zulus, Xhosas and Sothos I know women in our cultures are still not given the opportunity so 
when we come to the college we are coming with that to the college. Even if they are trying to put women here, people are still having that thinking. (Participants)

In this college, affirmative remedies (Fraser 1997:23) were used, such as the module Gender and Theology, which was partly aimed at correcting gender discrimination, however without disturbing the underlying framework that generated it, like deeper patriarchal attitudes. This is an add-on approach as it does not involve a restructuring of the curriculum and according to Cross (2004:402) is unable to promote equity and social justice effectively. In contrast, transformative remedies (Fraser 1997:27) seek to put right inequitable outcomes precisely by 'restructuring the underlying generative framework', that is, the processes that produce them.

In terms of issues of sexuality, the college was friendly to differing sexual orientations, but the church could not give its blessing to same-gender unions. Even though students related an incident wherein a student 'came out' during his preaching class and described the investigation of sexual harassment by a male staff member towards students, students were generally reluctant to voice an opinion. Like the issue of gender, conservative parts of the church deal differently with this issue and it would seem that students when among peers did not want to take a side.

The overwhelming theme in this college was the lack of openness in the community, which impacted the campus climate negatively and hence the facilitation of diversity. For example, students felt demeaned because of a lack of study skills as many had only completed a matriculation certificate, with English being their second, third or fourth language. As a student stated:

I am dissatisfied with the way that some of the lecturers treat us as students of a different colour. We feel that we are undermined, we cannot think. (Participant)

This highlights that educators need to reconsider assessment criteria and critique stereotypical images that misrepresent information about students (Hill et al. 2009:12) who are 'other' and do not come with the same level of preparedness or worldviews. Educators also need to appraise their own personal and institutional ideologies by considering their own social and personal contradictions in these matters of diversity (Brookfields 1995).

Almost all students were deeply influenced by the hierarchical and authoritarian nature of the church. There was also a strong authoritarian management style in the college, which students found overbearing and patronising. This 'fear of authority' rendered many students voiceless in taking up challenges. Students felt that management insisted on conformity without negotiation. They felt that a docile kind of acceptance of institutional dogma was expected, which created an 'us' and 'them' gap:

Basically the students were chewed because nobody tells authority what to do. Authority is authority here and that is sad. (Participant)
My understanding of formation is that my character is supposed to be bold, but right now my spirit is broken down - I am treated like a 5-year-old. (Participant)

The level of tolerance is very, very low, if I may put it that way ... you cannot be different, you cannot go against the grain, you cannot think out of the box, because then you either are labelled as trying to think, oh, you think you are better ... and that is not going to work. (Participant)

In preparing students for ordination, one of the key responsibilities of the college towards students is the facilitation of self-awareness and other awareness as a basis for healthy professional relationships. An important resource is formation groups, support groups for 'discussion of matters of common concern and spiritual activities'. They are intentionally racially and gender diverse, made up of a staff member and eight students. Students stated that because there was no trust and openness in the community, these groups were yet another structure where students were simply conforming to the requirements. In the groups there was a lack of self-awareness and cultural awareness, a lack of confidentiality about personal issues, and some students felt that staff were untrained in formation processes:

I see this place for academics. Yes, I have experienced [living] with other cultures and [all] that, but I do not feel that togetherness. (Participant)

What bothers me is that nobody cares about you. Surely we have got to have some sort of care, because I am supposed to be pastoral in a community where we care for each other. (Participant)

It is important to note that students' campus experiences are positive when their understanding of God is strengthened by classroom and campus experiences and supported by the opportunity to thrive socially, as well as quality relationships with other students and faculty members. Paredes-Collins states, 'research indicates that a positive climate is essential to promote spiritual growth for students' (2013:125). However, students generally felt they were not treated with respect as individuals and were not given the right to be heard, which resulted in a lack of openness in the community. This, in turn, resulted in a lack of safe spaces to discuss issues of diversity, which is critically related to students' ministerial identity development. Also key to note here is that students needed to prove themselves worthy within denominational assessment processes and were more focused on obtaining the credentials for ministry than on real learning. The last thing students were comfortable doing was exposing those areas of their lives and faith that were in need of stretching and growth, or even revision. They perceived the risk to be too high. If there is no culture of trust within the community, learning is not maximised and students go through the motions simply to conform to the requirements. This lack of openness that is modelled within the institution also becomes a way to treat the other. It impacted on how students related to each other cross-culturally; these limiting assumptions perpetuated doubts about the other that permeated college life. It would seem that issues that are not accepted become hidden. Issues are then not given a voice because of the fear of victimisation: 
We have not engaged in that kind of debate, you know. I think it is there in the back of all our minds, but I think everybody just says, 'you know what, let's just leave it as it is and just move on; maybe a miracle will happen, I do not know (laughing)'. So there is not, personally, a space for dealing with these kind of issues.

People are scared to voice out their opinion because it could impact on your ordination, you could be viewed negatively as being against authority ... issues end up in the community group and nobody was willing to take it up ... people were quiet, people just did not raise issues ... they are scared of being victimised. (Participants)

These scenarios reported above had the potential to close down the possibility of genuine dialogue and resulted in students feeling uncertain and frustrated and seeing no progress. This highlights a lack of relational structures for dealing with issues of diversity. This situation was aggravated by the taken-for-granted idea that the college was very diverse, leaving no reason to discuss that diversity and whether or not it translated into student integration. The assumption was made that living in community was sufficient to help students 'rub against' each other. However, formation does not happen by osmosis but is built in community through the integration of personal and community formation (Tatum 1997).

Even though this college had many structures for formation, the potential was not maximised because community was not nurtured and prioritised as much as the academic dimensions of the institution. The college mistook rhetoric for action and segregated the issue of diversity from other institutional concerns and priorities. Initiatives for diversity require intention and rooting out discrimination of all kinds. What is needed is the facilitation of a constructive educational environment and a commitment as an institutional priority (Allen 2006; Anderson 2007). Institutional structures matter in the process of identity transformation (Christerson, Edwards \& Emerson 2005), and until institutions tackle the problem at a structural level, it becomes difficult to sustain that alignment.

\section{Discussion}

The focus of the study was to understand how theological institutions manage diversity within their institutional culture, so as to understand how this equips and forms future Christian leaders. From the two very different ethnographies, we found different institutional cultures, each shaped over time by its mission, history, context and location. In one institution we found a disengaged stance towards diversity issues; there was a 'sharing of spiritual values' (Fubara et al. 2011:112) but little sharing of cultural ones. In this college, diversity did not include sexual orientation, religious diversity or, for some, denominational diversity. In the other institution we found an awareness of diversity, however without structure or alignment to make a significant difference. As in Fubara's research, 'these institutions face a certain tension between embracing and rejecting diversity' (2011:112). We also found some commonalities and paradoxes in attending to diversity.
In both institutions, the interactions between groups reflected very much a microcosm of South African society with its associated behaviours and attitudes. It is true that an institution's culture is not really a self-contained culture; it is more accurately a subculture of the broader social and religious world outside the institution. Students are keenly aware of the historical legacy of apartheid and the broader context - the inequality, racial stereotypes and separate realities. When institutions do not employ initiatives for diversity or engage in a passive role as regards race relations on campus, negative reactions and misunderstandings among students are likely to occur (Steele 1995:176-190), as evidenced by this study.

Even though students were highly committed to racial justice and understanding how diverse perspectives could enrich an understanding of the Christian life, there was a lack of open spaces within the institutions to dialogue on issues of diversity in a constructive way. There was generally a culture of silence, as students were afraid to speak because of the fear of being victimised and jeopardising their chances of ordination. Because Institution A promoted a colour-blind theology - that God cares about us as individuals and that our identity is 'in Christ' rather than in our ethnicity - there was then little room for dialogue. In Institution B, even though an awareness of diversity was seen as important, the relational dimensions were superficial with a lack of real community as the formation structures were not working. Both these institutions were not in possession of diversity grammar (Booysen et al. 2007).

This study highlights that students are being educated and formed within a particular institutional culture, inside the ethos and values of the broader church denomination. Hence it is important to understand how churches socialise their members, because churches largely reflect the social divisions of society. This is because churches are structured in patriarchal and hierarchical ways with their authoritarianism. As Kee states (2006:86), 'it ensures that the male prevails over the female and the clergy over the laity hence the roots of oppression lie deeper'. People are being socialised within these Christian communities through systems of meanings: scriptural beliefs, communal rituals and shared traditions. It is important to note that social identities are learned and are an outcome of social practices. The problem is that there is a failure to see how all sorts of language and behaviour reinforce what continues to be an uneven playing field. These findings cannot be reduced merely to a lack of interpersonal empathy or competency in theological education but highlight that in religious environments there are complex relationships of reproduction and the challenge of unequal relationships of dominance, compliance, resistance and change. For example, because of sexist ecclesial attitudes and practices most women experience the greatest imbalances of power and the abuse of patriarchal privilege. As Ryan and Shefer point out (2007):

[I]n church women are frequently excluded from leadership, most liturgy and church pronouncements are couched in sexist 
language, God is almost exclusively imaged in male metaphors and scripture is interpreted uncritically and androcentrically. (pp. 85-86)

What matters is to identify the structures of power, the ecclesial rituals and social practices that produce discriminatory outcomes. This involves the analytic skill to unpack how these systems of oppression in the church intersect, co-construct and constitute each other (Steyn 2011:20).

These ethnographies reveal that practices in the church are shaped by religious discourses that influence how diversity is dealt with. For example, in Institution A, theologically, racism was viewed as personal sin (Edgell Becker 1988). In this theological worldview, the wrongs of racial discrimination are dealt with by looking inward and dealing with individual prejudice; it can be solved by the repentance and conversion of the sinful individuals at fault. In Institution B, theologically, sin and salvation were seen as having deeply social dimensions, seen as a function of power, class and systems of domination. In this theological view, social systems and structures have to be addressed and, if corrected, will impact the effects of personal racial prejudices. As seen with this example of racism, it is important to understand the underlying theological criteria that are brought to assumptions and conceptualisations. The point of highlighting identities or differences is to show the implicit values and norms that need to be thoroughly articulated, analysed, evaluated, deconstructed and reconstituted (Lee 2009:19).

In terms of the interplay between diversity and professional development, ministerial formation is the vehicle to facilitate conversations, because it deals with issues of identity development. Both institutions failed to link attending to diversity with ministerial formation. Issues of identity were not embedded in ministerial formation due to the lack of broad understanding of ministerial formation and a lack of staff capacity in formation. A recent study showed that the formational mandate is still being marginalised by the focus of academic instruction, together with the demands of accreditation (Naidoo 2011:121). Among students there are a variety of ideological and value commitments shaped by theological, racial, ethnic, class and gendered experience and heritage. Considering prior socialisation, formation facilitates students' ongoing identity development (including cultural identity), moving toward more authentic identity and authenticity vocation (Borysenko 1999; Palmer 2000). This is made possible through the process of conscientisation (Freire 1970), from confrontation (of the system) to self-awareness (identity construction and social location) to re-articulation (construction of a new world) (Hill et al. 2009:18). Student encounters with 'otherness' provide a vehicle for awareness and appreciation of identity differences, particularly around spiritual development. Thus the training experience is a crucial time for future ministers to nurture a mature development of occupational and personal identity within their social location to enable a coherent understanding of the role and function in ministry (Heitink 1993:317).
What this study puts into clear focus is that a lack of consciousness of the way in which institutions are organised will hold direct consequences for students' identity and transformation. In managing diversity, there is a distinction between difference management that encourages window-dressing and that which aims at profound transformation. Theological institutions educate students for service in a democratic and pluralistic society and need to confront the issues of diversity even though it is a challenging and often divisive work. Institutions need to articulate clearly what they will and will not include under the umbrella concept of diversity, expect difficult conversations to occur and be willing to accept the tension as a healthy way to have a dialogue. Even though it has now become unacceptable and politically incorrect for higher education institutions not to take diversity seriously, theological institutions need to do more to prepare students from different cultural and racial backgrounds for effective ministry in a variety of cultural settings. The critical task is to build institutional capacity to create the conditions to capitalise on the benefits of diversity.

This area of diversity in Christian higher education in South Africa is understudied and undertheorised, and there is room for a great deal of expansion. This study only scratched the surface in terms of students' experiences of social interactions of diversity. Future research could investigate various intersections of diversity, together with the social location and spiritual development that makes South Africa an interesting case study and contributes to international scholarship as well.

\section{Conclusion}

This research has highlighted how two theological institutions have been attending to diversity within their institutional culture. The presence of a range of cultural, social, personal and ecclesial difference poses particular challenges to theological institutions with the interplay of formation in preparing effective religious leaders. Once the institutional culture begins to see its own situatedness, it can begin to shed its parochial and paternalistic tendencies (Foster 2002:16). This is only possible when 'whiteness' or 'blackness' or heterosexuality or being male is no longer conceived as the norm and is seen as one contextual position among many, albeit often carrying with it particular privileges and considerable power. Diversity is a challenging, sensitive and often divisive task. As Speller and Seymour (2002) state so clearly:

[T] he problem diversity poses is to locate a common intersection, among and between the ideas, myths and dreams undergirding the various types of difference and then to create an educational and conversational space sturdy enough to allow the restructuring of 'what counts' as theological education. (p. 60)

\section{Acknowledgements}

This research was supported by grants from the National Research Foundation and is gratefully acknowledged. 


\section{Competing interests}

The author declares that she has no financial or personal relationships that may have inappropriately influenced her in writing this article.

\section{References}

Abadeer, A., 2009, 'Seeking redemptive diversity in Christian institutions of higher education: Challenges and hopes from within Christian higher education' Christian Higher Education 8(3), 187-202. http://dx.doi.org/10.1080/1536375 0902782373

Allen, W.R., 2006, 'Sticks, stones, and broken bones: Rhetoric and reality in the University of Michigan affirmative action cases', in W. Allen, M. Bonous-Hammarth \& R. Teranishi (eds.), Higher education in a global society: Achieving diversity, equity, and excellence, pp. 203-226, Elsevier, San Diego, CA.

Anderson, A., 2005, 'New African initiated pentecostalism and charismatics in South Africa', Journal of Religion in Africa 35, 66-92. http://dx.doi.org/10.1163/ 1570066052995843

Anderson, J., 2007, 'Eight crucial steps to increase diversity', Chronicle of Higher Education 54(5), 1-36.

Balcomb, A., 2004, 'From apartheid to the new dispensation: Evangelicals and the democratization of South Africa', Journal of Religion in Africa 34, 5-38. http:// dx.doi.org/10.1163/157006604323056705

Bernstein, B.B., 2000, Pedagogy, symbolic control, and identity: Theory, research, critique, Rowman \& Littlefield, London.

Booysen, L., Kelly, C., Nkomo, M.S. \& Steyn, M., 2007, 'Rethinking the diversity paradigm: South Africa practices', International Journal of Diversity in Organizations, Communities and Nations $7(4), 1-10$. http://dx.doi.org/10.18848/ Organizations, Communities and
1447-9532/CGP/v07i04/58021

Borysenko, J., 1999, A woman's journey to God, Riverhead Books, New York.

Brookfields, S., 1995, Becoming a critically reflective teacher, Jossey-Bass, San Francisco, CA.

Chapman, A.R. \& Spong, B., 2003, Religion \& reconciliation in South Africa: Voices of religious leaders, Templeton Foundation Press, Philadelphia, PA.

Christerson, B., Edwards, K.L. \& Emerson, M.O., 2005, Against all odds: The struggle for racial integration in religious organizations, New York University Press, New York.

Conde-Frazier, E., Kang, S. \& Parrett, G., 2004, A many colored kingdom: Multicultural dynamics for spiritual formation, Baker Academic, Grand Rapids, MI.

Creswell, J.W. \& Plano Clark, V.L., 2011, Designing and conducting mixed methods research, 2 nd edn., Sage, New York.

Cross, M., 2004, 'Institutionalising campus diversity in South Africa higher education: Review of diversity scholarship and diversity education', Higher Education 47, 387-410. http://dx.doi.org/10.1023/B:HIGH.0000020854.04852.80

Cross, M. \& Naidoo, D., 2012, 'Race, diversity pedagogy: Mediated learning experience for transforming racist habitus and predispositions', Review of Education Pedagogy, and Cultural Studies 34(5), 227-244. http://dx.doi.org/10.1080/10714 413.2012.735558

Donald, J. \& Rattansi, A. (eds.), 1992, Race, culture and difference, Sage, London.

Dreyer, J.S., 2012, 'Practical theology in South Africa', in B.J. Miller-McLemore (ed.), The Wiley-Blackwell companion to practical theology, pp. 505-514, Wiley Blackwell, San Francisco, CA.

Edgell, B.P., 1988, Congregations in conflict: Cultural models of local religious life, John Knox Press, Atlanta, GA.

Foster, C.R., 2002, 'Diversity in theological education', Theological Education 38(2), 15-37.

Fraser, F., 1997, Justice interruptus - Critical reflections on the 'Postsocialist' condition, Routledge, New York.

Freire, P., 1970, Pedagogy of the oppressed, Continuum, New York.

Froehle, M.C., Maloney, D. \& Lassiter, K., 2014, 'Complex identities in ministry formation: Processors of reflection, refraction and diffraction in the contexts of difference in theological field education', in P. Couture, R. Mager, P. McCaroll \& N. Wigg-Stevenson (eds.), Complex identities in a shifting world, pp. 19-30, LIT Verlag, Zurich.

Fubara, E.I., Gardner, M.T. \& Wolff, J.S., 2011, 'Applying diversity management principles to institutions of Christian higher education', Christian Higher Education 10(2), 112-131. http://dx.doi.org/10.1080/15363751003715767

Geertz, C., 1973, The interpretation of cultures, Basic Books, New York.

Heitink, G., 1993, Practical theology - History, action, domains: Manual for practical theology, Eerdmans, Grand Rapids, MI.
Hill, J.A., Harris, M.L. \& Martinez-Vazquez, H.A., 2009, 'Fighting the elephant in the room: Ethical reflections on white privilege and other systems of advantage in the room: Ethical rellections on white privilege and other systems of advantage in the teaching of religion', Teaching Theology
org/10.1111/j.1467-9647.2008.00471.x

Hindman, D.M., 2002, 'Form splintered lives to whole persons: Facilitating spiritual development in college students', Religious Education 97(2), 165-182. http://dx. doi.org/10.1080/00344080290060923

Hurtado, S., Milem, J.F., Clayton-Pedersen, A.R. \& Allen, W.R., 1998, 'Enhancing campus climates for racial/ethnic diversity: Educational policy and practice', Review of Higher Education 21, 279-302. http://dx.doi.org/10.1353/rhe.1998.0003

Kee, A., 2006, The rise and demise of black theology, Ashgate, Hants, UK.

Kleinman, S., 1984, Equals before God: Seminarians and humanistic professionals, University of Chicago Press, Chicago, IL.

Kuperus, T., 2011, 'The political role and democratic contribution of Churches in postapartheid South Africa', Journal of Church and State 53(2), 278-306. http://dx.doi. org/10.1093/jcs/csr030

Lee, S.K., 2009, 'Engaging difference in pastoral theology: Race and ethnicity, The Journa of Pastoral Theology 19(2), 1-20. http://dx.doi.org/10.1179/jpt.2009.19.2.002

McIntosh, P., 2005, 'White privilege: Unpacking the invisible knapsack', in P.S Rothenberg (ed.), White privilege: Essential readings on the other side of racism pp. 109-114, Worth, New York.

Meyer, A.J., 2009, Realizing our intention: A guide for churches and colleges with distinct missions, ACU Press, Abilen, TX.

Naidoo, M., 2011, 'An empirical study on spiritual formation at Protestant theological training institutions in South Africa', Religion and Theology 18, 118-146. http:// dx.doi.org/10.1163/157430111X613692

Naidoo, M. (ed.), 2012, Between the real and the ideal: Ministerial formation in South Africa churches, UNISA Press, Pretoria.

Naidoo, M., 2014, 'Racial diversity and social cohesion in South African theological education', The South African Baptist Journal of Theology 23, 242-255.

Naidoo, M., 2015, 'Transformative remedies towards managing diversity in South African theological education', HTS Theological Studies 71(2), 1-7. http://dx.doi. org/10.4102/hts.v71i2.2667

Neuman, L.W., 2006, Social research methods, Pearson, Boston, MA.

Nussbaum, K.B. \& Chang, H., 2013, 'The quest for diversity in Christian higher education: Building institutional governance capacity', Christian Higher Education 12(1-2), 5-19. http://dx.doi.org/10.1080/15363759.2013.740383

O'Reilly, K., 2009, Key concepts in ethnography, Sage, London.

Ouichi, W.G. \& Wilkins, A.L., 1985, 'Organizational culture', Annual Review of Sociology 11, 457-483. http://dx.doi.org/10.1146/annurev.so.11.080185.002325

Palmer, P., 2000, Let your life speak, Jossey-Bass, San Francisco, CA.

Paredes-Collins, K., 2009, 'Institutional priority for diversity at Christian institutions', Christian Higher Education 8, 280-303. http://dx.doi.org/10.1080/15363750 902821197

Paredes-Collins, K., 2013, 'Cultivating diversity and spirituality: A compelling interest for institutional priority', Christian Higher Education 12(1-2), 122-137. http:// for institutional priority', Christian Higher
dx.doi.org/10.1080/15363759.2013.739436

Perez, J., 2013, 'Diversity at Christian colleges: It's about mission', Christian Higher Education 12(1-2), 20-34. http://dx.doi.org/10.1080/15363759.2013.739438

Riebe-Estrella, G., 2009, 'Engaging borders: Lifting up difference and unmasking division', Theological Education 45(1), 19-26.

Ryan, M. \& Shefer, T., 2007, 'An exploratory study of the impact of a postgraduate module on feminist theology on the consciousness and practice of a group of church-going women', Journal of Theology for Southern Africa 129, 82-98.

Schon, D., 1991, The reflective practitioner, Basic Books, New York.

Smircich, L., 1983, 'Concepts of organizational culture and organizational analysis', Administrative Science Quarterly28, 339-358. http://dx.doi.org/10.2307/2392246

Smith, D.G. \& Schonfeld, N.B., 2000, 'The benefits of diversity: What the research tells us', About Campus, 5(5),16-23.

Speller, J.M. \& Seymour, J.L., 2002, 'Reflections on institutional issues relate to race and ethnicity in ATS schools', Theological Education 38(2), 55-70.

Steele, S., 1995, 'The recoloring of campus life: Student racism, academic pluralism and the end of the dream', in J. Arthur \& A. Shapiro (eds.), Campus wars: Multiculturalism and the politics of difference, pp. 176-190, Westview Press, Boulder, CO.

Steyn, M. (ed.), 2011, Being different together: Case studies on diversity interventions in some South African organisations, iNCUDISA, Cape Town.

Swindler, A., 1986, 'Culture in action: Symbols and strategies', American Sociologica Review 51, 273-286. http://dx.doi.org/10.2307/2095521

Tatum, B.D., 1997, Why are all the black kids sitting together in the cafeteria? And other conversations about race, Basic Books, New York.

Wodak, R. \& Paul C. (eds.), 2005, New agenda in (Critical) discoursea, Benjamins, Amsterdam. 